RPA Journals

\section{ITHJ}

International Tourism and Hospitality Journal

Journal Homepage: https://rpajournals.com/ithj

\title{
Perceptions of Customers and Food and Beverage Managers (F\&B) regarding the Restaurants' Performance during the Egyptian Revolution of 2011
}

\author{
Ahmed Abd El Maksoud" \\ Ahmed E. Baiomy 2 \\ Ahmed Elias \\ Tamer Abbas ${ }^{4}$ \\ Faculty of Tourism and Hotel Management ${ }^{123 \times 4}$ \\ Helwan University, Cairo, Egypt ${ }^{1.2 .3 \times 4}$
}

\begin{abstract}
This study explores the perceptions of customers and Food and Beverage Managers (F\&B) regarding the restaurants' performance during the Egyptian Revolution of 2011. A multiple embedded case study was used as a research methodology involving sequential mixed methods. The present study utilized two methods of data collection: semi-structured interviews with F\&B managers and self-administered questionnaires filled out by customers. Purposive sampling was used to collect qualitative data, whereas convenience sampling was used to collect the quantitative data. The findings indicated that F\&B did not have a standard action plan to follow during the political crisis of 2011. Although this study also showed that customers were satisfied with the quality, quantity, and variety of food offered, they were not satisfied with the hotel restaurants' promotions. This research will provide a useful steppingstone to future studies about hotel operational procedures during the current crisis of COVID-19 in the Egyptian Hospitality industry. Recommendations are suggested based on the findings of this study.
\end{abstract}

Keywords: Restaurants' Performance; Operational Procedures During; Crises; Five-Star Hotels

*Corresponding author: Ahmed Abd El Maksoud; Email: ahmedelsayedth@hotmail.com DOI: https://doi.org/10.37227/ITHJ-2020-03-112

\section{Introduction}

A crisis is a major unpredictable event that may significantly damage an organization's reputation (Barton, 2008). A crisis is a situation that creates an abrupt or sudden change in one or more of the primary systematic variables (Nassar, 1995). In general, a crisis is a situation requiring radical management action in response to events beyond the internal control of the organization, necessitating urgent adaptation of marketing and operational practices to restore the confidence of employees, associated enterprises and consumers in the viability of the destination (Beirman, 2003; Malhotra and Venkatesh, 2009).

The Arab Spring revolution was the most significant crisis, which hit hard the 
tourism industry in the Arab region (Abou Elfadl, 2012). This crisis has started in Tunis after decades of bureaucratic spontaneous protests and demonstrations, which later spread to all over Egypt, Yemen, Bahrain, Libya, and Syria. A wave of inversions experienced in the last two years, shifting the balance of power in the Middle East and North Africa. Egypt suffered a series of political events during 2011, which lead to uncertainty in the Egyptian economy. According to the World Tourism Organization (2011), fourteen million international tourists arrived in Egypt in 2010, generating 13 billion US dollars in tourism receipts, however, international tourist arrivals declined by 32\% in 2011 because of political instability.

As a result, the Egyptian economy was suffered in many aspects. First, Egypt lost a considerable percentage of its potential national income and foreign currency usually generated by the tourism industry. Second, Egypt suffered substantial levels of unemployment as thousands of hotel employees were laid off, which affects the quality of service offered to customers at the five-star hotels in Cairo City in Egypt. Occupancy rates sharply decreased to $10 \%$ as many reservations were canceled (Abu al-Khair, 2011).

The Egyptian Ministry of Tourism (2011) estimated that Egyptian tourism might generate about 10 billion US dollars in 2011, compared to 12.53 billion US dollars in 2010 (see Table 1). The annual occupancy rates of Cairo hotels in 2009 and 2010 slightly decreased from 2008 by $3 \%$ and $5 \%$, respectively. However, the annual occupancy rate in 2011 sharply reduced by $38.2 \%$, which represents a massive decline in hotel occupancy rates. In other words, the occupancy rates of 2011 were approximately half the occupancy rates of 2008. Consequently, hotels lost a considerable percentage of their potential revenue during 2011, which leads to a severe negative impact on the Egyptian economy.

Table 1: The Annual Occupancy Rates of Cairo Hotels

\begin{tabular}{|c|c|c|c|c|c|c|c|c|c|c|c|c|c|}
\hline Year & Jan & Feb & Mar & Apr & May & Jun & July & Aug & Sep & Oct & Nov & Dec & Avg \\
\hline $\mathbf{2 0 0 8}$ & 81.6 & 81.2 & 81.3 & 76.8 & 79 & 74 & 75.4 & 76.1 & 78.1 & 81.5 & 76.1 & 76.5 & $\mathbf{7 8 . 1 \%}$ \\
\hline $\mathbf{2 0 0 9}$ & 72.2 & 74 & 74 & 74.2 & 75 & 75.3 & 77 & 75.9 & 74.9 & 78.5 & 77.5 & 79.5 & $\mathbf{7 5 . 6 \%}$ \\
\hline $\mathbf{2 0 1 0}$ & 72 & 76 & 74 & 74 & 68 & 66 & 74 & 84 & 75 & 59 & 82 & 73 & $\mathbf{7 3 . 8 \%}$ \\
\hline $\mathbf{2 0 1 1}$ & 74.5 & 15.3 & 29.9 & 29.5 & 34.1 & 56.9 & 45.3 & 52.3 & 46 & 46.1 & 24.4 & 24.4 & $\mathbf{3 9 . 9}$ \\
\hline
\end{tabular}

Although many crises affected the hospitality industry's growth not only in Egypt but also all over the world, those crises helped hotel managers to think about operational strategies to overcome the effects of these crises (Glaesser, 2003). The hospitality industry is highly susceptible and can be negatively affected by any crisis. Hotel restaurant crises can range from a natural disaster to the loss of significant customers. A little is known about perceptions of customers and Food and Beverage managers $(F \& B)$ regarding operational procedures of Cairo hotel restaurants during crises in Egypt, particularly during the Egyptian revolution of 2011.

The hotel industry in Cairo makes a vital contribution to the Egyptian economy in terms of foreign exchange earnings and job opportunities (Beirman, 2002). The annual occupancy rates of Cairo hotels have been sharply declined from $73 \%$ in 2010 to $39.9 \%$ in 2011 due to the Egyptian revolution (see Figure 1).) As a result, increasing hotel occupancy is the primary objective of a hotel's management because it directly impacts on hotel revenues (Jeffrey and Barden, 2000). In the context of hotel restaurants, around 28 percent of average hotel revenues come from restaurants' sales. Therefore, this paper aims to evaluate the operational procedures adopted by hotel restaurants during crisis periods. 
This aim will be achieved through the following objectives:

- Identify the role of restaurant managers with F\&B managers during crises.

- Identify customers' perceptions of hotel restaurants' performance and their quality of service through crises

- Explore the best methods used to address the lack of works in restaurants in crises.

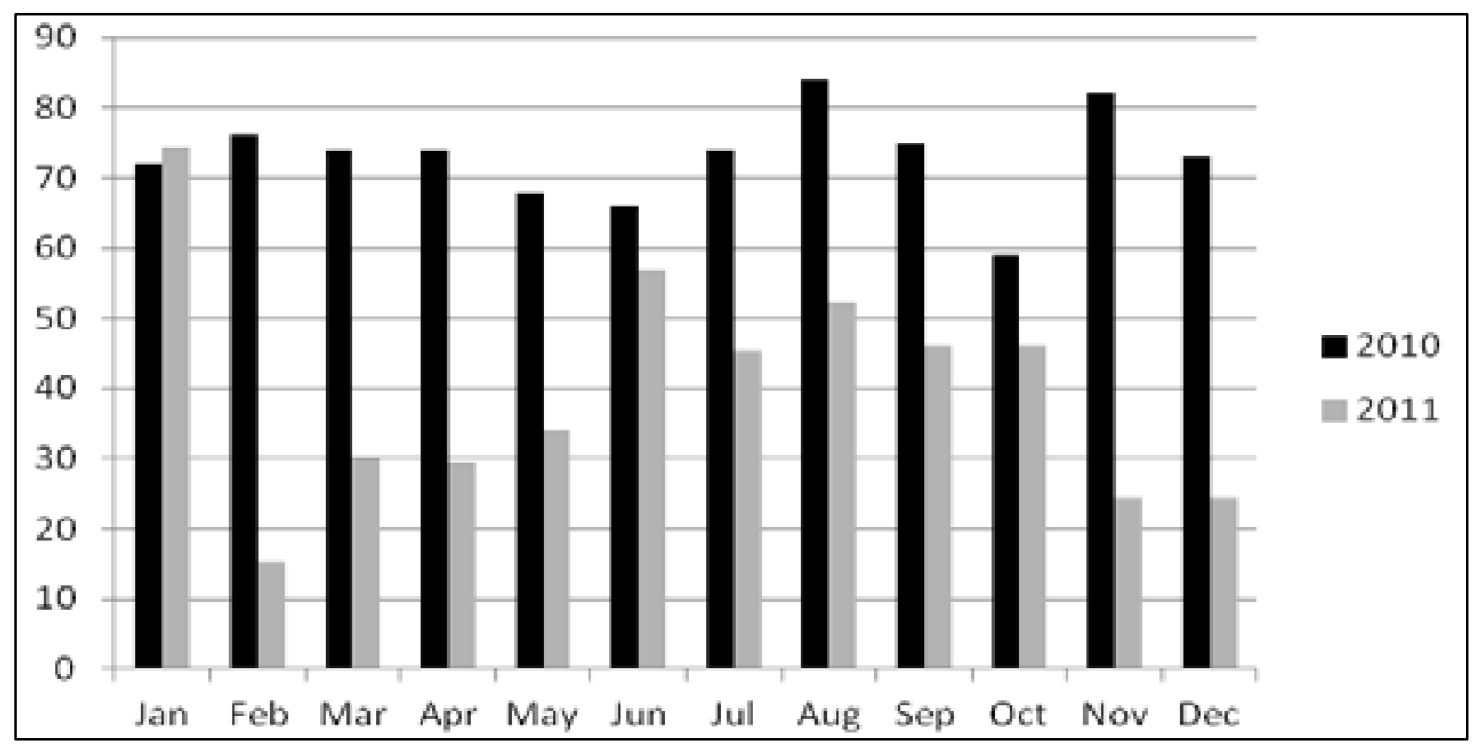

Figure 1: Monthly Occupancy Rates of Cairo Hotels 2010:2011

Source: Egyptian Ministry of Tourism Occupancy Reports (2011)

\section{Literature Review}

According to WTO (2003), a crisis is an unexpected event that affects traveller confidence in a destination and interferes with the ability to continue operating normally. A crisis has potential undesirable consequences that influence operational procedures in hotel restaurants (Boin and Lagadec, 2000). Stafford et al. (2002) showed that crises could be divided into three broad categories and seven specific categories (see Table 2). The three broad categories are the physical environment, the social environment (external factors), and management failures (internal factors). The seven specific types are confrontation, deception, malevolence, misconduct, natural disaster, skewed values, and technology failure. 
Table 2: Types of Crises

\begin{tabular}{|c|c|c|c|}
\hline $\begin{array}{l}\text { Major } \\
\text { factors }\end{array}$ & $\begin{array}{c}\text { Specific } \\
\text { environment }\end{array}$ & Type of crisis & Example of crisis \\
\hline \multirow{4}{*}{$\begin{array}{l}\text { External } \\
\text { factors }\end{array}$} & \multirow[t]{2}{*}{$\begin{array}{l}\text { Physical } \\
\text { environment }\end{array}$} & Natural disaster & $\begin{array}{l}\text { Earthquake damages a hotel property; volcano } \\
\text { eruption scares away tourists }\end{array}$ \\
\hline & & $\begin{array}{l}\text { Technology } \\
\text { failure }\end{array}$ & $\begin{array}{l}\text { Oil spill contaminates a resort beach and prevents } \\
\text { tourists from visiting the resort. }\end{array}$ \\
\hline & \multirow[t]{2}{*}{$\begin{array}{l}\text { Human or social } \\
\text { environment }\end{array}$} & Confrontation & $\begin{array}{l}\text { Labor strike disrupts normal operations, special- } \\
\text { interest group boycotts restaurant. }\end{array}$ \\
\hline & & Malevolence & $\begin{array}{l}\text { Terrorists attack; hackers introduce a virus into } \\
\text { computer reservation systems. }\end{array}$ \\
\hline \multirow[t]{3}{*}{$\begin{array}{l}\text { Internal } \\
\text { factors }\end{array}$} & \multirow{3}{*}{$\begin{array}{l}\text { Management } \\
\text { failure }\end{array}$} & Skewed values & $\begin{array}{l}\text { Cruise ships dump waste oil into the ocean } \\
\text { (ranking shorter in costs over concern for the } \\
\text { environment. }\end{array}$ \\
\hline & & Deception & $\begin{array}{lllll}\text { Restaurant knowingly } & \text { serves } & \text { spoiled } & \text { or } \\
\text { contaminated food items. } & & & \\
\end{array}$ \\
\hline & & Misconduct & $\begin{array}{l}\text { Corporate CFO embezzles funds or receives } \\
\text { kickbacks. }\end{array}$ \\
\hline
\end{tabular}

Source: Stafford et al. (2002)

Most previous studies examined crisis management from either a descriptive or historical perspective. For example, Ulmer and Sellnow (2000) provided a case-based historical and ethical analysis in presenting the crisis of Jack in the Box restaurant chain. Stafford et al. (2002) detailed the reaction of the USA hospitality industry to the events of the 11th of September, 2001. Several authors described different occurrences of terror in the hospitality and tourism contexts. For instance, Barton (1994) presented general guidelines for managerial preparations required in times of crisis. However, few studies have focused on hotel managers as a unit of analysis and investigated their day to day struggle with crises in his business.

Although managers face several challenges in a continuously changing environment, they have to keep their hotels at the standard, which achieves the customers' expectations (Ribaric, 2010). Robbins and Coulter (2003) suggested that managers should focus on the effective and efficient completion of organizational work activities. Evaluating the importance of practices, managers focus on government support and marketing. Their responses suggest that their focus is on finding actions to combat the effects of the crisis by improving their organizations' effectiveness. Government support and marketing efforts are measures to enhance the efficacy because they can assist in increasing the volume of potential business transactions in the long run and therefore support the attainment of the organization's most essential goals (Kaplanand Norton, 1992).

In terms of anti-crisis strategies, Barton (2008) explained that many hotels had chosen a more balanced marketing strategy. These hotels have resumed their ancient tactics to create more personal connections, placing a more considerable effort to develop a lasting business relationship. This strategy should be applied primarily because, in recent years, the development of the Internet has led to the depersonalization of hoteliers' relationships with customers. Most hotels are focused on prioritizing policies time to become a more productive business. Internet and other electronic forms of marketing will supplement and improve sales department efforts and will not replace them. The Internet might have a significant impact in terms of sales, but not the only way to do marketing. 
Table 3 shows the benefits that can be generated by the continual development of the relationships with consumers during a crisis period.

Table 3: Benefits of Relationships with Customers during Crisis Periods

\begin{tabular}{|c|l|}
\hline \multicolumn{1}{|c|}{ Benefits for the customers } & \multicolumn{1}{|c|}{ Benefits for F\&B managers } \\
\hline \multicolumn{1}{|c|}{ Bigger added value } & \multicolumn{1}{c|}{ Sales increase } \\
\hline $\begin{array}{l}\text { The value is for the customer the result of } \\
\text { what he gives and what he receives back } \\
\text { from the hotel keeper (cost versus quality, } \\
\text { satisfaction, specific benefits) }\end{array}$ & $\begin{array}{l}\text { Sales analysis shows that, over the years, loyal } \\
\text { customers tend to buy more services offers by hoteliers } \\
\text { who are in a durable relationship. }\end{array}$ \\
\hline $\begin{array}{l}\text { Benefits of truth } \\
\begin{array}{l}\text { These benefits accrue, also to truth company, } \\
\text { reduced feelings of anxiety and high comfort } \\
\text { in knowing what to expect from the hotel } \\
\text { manager }\end{array}\end{array}$ & $\begin{array}{l}\text { There are many costs associated with attracting new } \\
\text { customers (advertising and other promotional costs, } \\
\text { operating costs, operating costs and achieving } \\
\text { customer account, and so in). Instead, existing } \\
\text { customers, over time, learn to use the service, which } \\
\text { will lead to lower customer service costs. }\end{array}$ \\
\hline $\begin{array}{l}\text { As time passed, between the client and hotel } \\
\text { keeper develops familiarity and stable social } \\
\text { relationships. }\end{array}$ & $\begin{array}{l}\text { Satisfied customers loyal probably will promote the } \\
\text { hotel. }\end{array}$ \\
\hline Benefits resulted from special treatments & \multicolumn{1}{|c|}{ Keeping the employees } \\
\hline $\begin{array}{l}\text { These unique treatments include additional } \\
\text { payment terms, obtaining a special price. }\end{array}$ & $\begin{array}{l}\text { People like to work for companies whose clients are } \\
\text { satisfied and loyal. }\end{array}$ \\
\hline
\end{tabular}

Source: Iordache (2012)

\section{Research Methodology}

A multiple embedded case study was used as a research methodology to fully explore all the issues related to this study through involving sequential mixed methods. A case study strategy regularly uses either qualitative or quantitative methods or both to collect and analyze data (Yin, 2013). A case study also may involve different data collection methods, such as questionnaires, interviews, observations, and document analysis (Saunders, Lewis, $\&$ Thornhill, 2012). The present study adopted two methods of data collection, which are semi-structured interviews with F\&B managers and self-administered questionnaires filled out by customers. Cairo is the capital of Egypt, and it has many tourist attractions. According to the Egyptian Ministry of Tourism (2011), Cairo has 176 hotels and 28525 hotel rooms. Among these hotels, there are 27 five-star hotels. Most of the famous hotel management companies, such as Hilton, Sheraton, Marriott, Four Seasons, Grand Hyatt, and Accor, operate hotels in Cairo. In normal circumstances, the average annual occupancy rate of Cairo hotels is about $75 \%$. The average rack rate for a five-star single hotel room is between US\$ 180 and US\$ 300 per night and between US\$ 250 to US\$ 330 for a double room.

In terms of sampling, purposive sampling was used to collect qualitative data, while convenience sampling was used to collect quantitative data. Semi-structured interviews were used to gain a complete set of data and a better understanding of the operational procedures of hotel restaurants during crises to develop the best practice procedures. The sample size of this study is 15 out of 27 five-star hotels. Fifteen semi-structured interviews were held with F\&B managers, i:e., MGR1; MGR2; MGR3; MGR4; MGR5; MGR6; MGR7; MGR8; MGR9; MGR10; MGR11; MGR12; MGR13 MGR14; MGR15). The semi-structured interview's schedule included open and close-ended questions. The schedule of the interview was pre-piloted to find out if additional questions were required, 
or some current questions should be excluded. Each interview lasted around 40-50 minutes.

The semi-structured interview included the following questions as follows:

- How long have you been working in this position?

- What kind of crises did your restaurant face since 2011 ?

- Were the crisis periods expected or not?

- Did the crises affect your restaurant?

- If yes, please explain its effects on the following:

\begin{tabular}{lccr}
\multicolumn{1}{c}{ Attributes } & Increased & Declined & Stable \\
Average annual occupancy of restaurants & $\square$ & $\square$ & $\square$ \\
The average number of guests & $\square$ & $\square$ & $\square$ \\
Number of reservations cancelled & $\square$ & $\square$ & $\square$ \\
The profitability of hotel restaurants & $\square$ & $\square$ & $\square$ \\
Cost reduction of hotel restaurants & $\square$ & $\square$ & $\square$ \\
Menu prices of restaurants & $\square$ & $\square$ & $\square$ \\
Operational hours in restaurants & $\square$ & $\square$ & $\square$ \\
Guest seat turnover. & $\square$ & $\square$ & $\square$ \\
Guest satisfaction & $\square$ & $\square$ & $\square$ \\
Number of employees & $\square$ & $\square$ & $\square$ \\
Employees performance & $\square$ & $\square$ & $\square$ \\
Employees satisfaction & $\square$ & $\square$ & $\square$ \\
Service quality. & $\square$ & $\square$ & $\square$ \\
Restaurant offers & $\square$ & $\square$ & $\square$ \\
Menu variety & $\square$ & $\square$ & $\square$
\end{tabular}

- What are the most common problems you face during the crisis period?

- Does the restaurant have a standard action plan to follow during a crisis period?

- If yes, please explain your operational procedures before, during, and after this period?

- How could you evaluate these procedures? The most effective and the least effective?

- If you have any suggestions to improve the service quality during crises, please mention here?

Besides, the questionnaire was designed and distributed to customers while eating in the sampled hotel restaurants during crises. The questionnaire form was developed based on the relevant review of the literature. A pilot study was conducted to maximize the reliability and validity of the questionnaire. Fifty questionnaire forms were distributed to guests who were visiting the sampled hotel restaurants during crises. The instructions and some questions were not clear the final questionnaire form was modified based on the pilot study. The questionnaire form was written and distributed in both the Arabic and English languages. 320 out of 450 distributed questionnaire forms were valid. The questionnaire form consisted of nine questions. Questions from one to three were about general information of the customer such as, how often do you eat in the restaurants during the last three years $(2011,2012,2013)$. Part two divided into two questions; the fourth question aimed to know the customer opinions about hotel restaurants to know the performance of restaurants during the period of crises through the Likert scale $(1=$ Very poor, $2=$ Poor, $3=$ Fair, $4=$ Good, 5 = Excellent). The fifth question was to identify what extend the customer 
agree about procedures of hotel restaurants in crisis period through the Likert scale $(5=$ Strongly agree, $4=$ Agree, $3=$ Natural, $2=$ Disagree, $1=$ Strongly disagree). Part three included personal profile questions: gender, age, and marital status.

\section{Reliability and Validity}

In qualitative research, reliability is frequently ignored owing to the difficulties in repeating it (Creswell \& Clark, 2007). Reliability is also linked with whether other studies would indicate a similar set of information. In the same respect, Saunders et al. (2012) showed that participation and researcher bias should be considered to confirm the reliability of data. First, participation bias occurs if the value of the information provided is insufficient. To deal with this error, interviewees have allowed the researcher to discuss operational performance in hotel restaurants during crises in considerable detail. Finally, researcher bias may occur if the data collected is interpreted using a range of analytical approaches. Thus, content analysis was the only approach used in this research to analyze all the interviews to avoid this particular bias. Validity refers to the quality of information collected by the researcher and whether it shows the phenomenon being examined (Veal, 2006). Hence, pilot testing of the interview questions was conducted in five hotels in order to ensure that these questions could be easily understood.

In terms of quantitative research, reliability represents those answers obtained from participants who are consistent and stable over time. The researchers used the pilot study to reduce reliability errors in conducting the questionnaire. Cronbach's alpha was applied to check the reliability and internal consistency of the construct. If the Cronbach's alpha is above 0.7, the sample scale will be reliable (Pallant, 2007). Cronbach's alpha of items used to measure constructs in this study was 0.87 . Regarding the validity of the questionnaire, the face validity was conducted in this study by sending the questionnaire to three $F \& B$ marketing experts.

\section{Data Analysis}

Content analysis was used to analyze the semi-structured interviews (Gray, 2004) because it is "a technique based on the manual or automated coding of transcripts, documents, (newspaper) articles or even audio and video material" (Cooper \& Schindler, 2011, p. 294). In this study, the content analysis started with the research questions. Then, the main sections and sub-sections were defined theoretically. After that, the text was coded according to these sections (Swift, 1996). The four major parts, which were essential to the research objectives, were: Work experience, type of crises, crises effect on a hotel restaurant performance, and joint problems during crises. After that, the sections were revised according to the research questions. The final step was to interpret the findings. In terms of quantitative data analysis, the Statistical Program for the Social Science (SPSS) version 20 was used to analyse it.

\section{Results and Discussion of Semi-Structured Interviews}

\section{Work Experience}

The findings showed that all F\&B managers had work experience during the Egyptian revolution of 2011, the highest tourism crisis in Egypt after the Luxor terrorist attack in 1998. Most F\&B managers indicated they started working in their positions either in 2009 or 2010, which means that all participants in this study will be able to answer any questions related to the hotel restaurant's performance during crises since 2011. 


\section{Type of crises and their effect on a hotel restaurant performance}

This question aims to illustrate the kinds of crises that F\&B managers have faced since 2011. Most F\&B managers agreed that the leading crises in Egypt were the $25^{\text {th }}$ of January revolution and the terrorist attacks after the 30th of June 2013. However, the size and effects of these crises are different between restaurants in one hotel to another. All F\&B managers agreed that these crises were unexpected and affected their hotel restaurants' performance. For example, many crashes have affected hotels nearby Tahrir Square, which resulted in a dramatic decrease in the number of guests; Cancellation of reservations and some of the hotel restaurants are even closed (MGR2; MGR5; MGR8; MGR10). Besides other crises, an international hotel chain company has broken its contract with the owner, which led to working without a sales plan; the percentage of hotel reservations decreased from $85 \%$ to less than $8 \%$, losing contracts with many governmental institutions. Most F\&B managers near Tahrir Square changed their operational plan in their restaurants because guests are more worried about their safety and security.

Fourteen out of fifteen F\&B managers agreed that the annual average occupancy of restaurants, the profitability of restaurants, and guest seat turnover were dramatically declined. However, MGR14 believed that the yearly average occupancy remains stable in his hotel restaurants. MGR6 and MGR14 indicated that employees' turnover has also been increased because most qualified employees have traveled abroad to find a better place to work. Also, most F\&B managers revealed that staff performance and satisfaction were declined because of no extra benefits for the staff, such as service charge and tipping. On the other hand, MGR1 and MGR9 explained that staff performance and their satisfaction levels have increased.

Although MGR7 and MGR10 have offered happy hour promotion and special offers for dinner menus like kids eat free with an adult, 13 out of $15 \mathrm{~F} \& \mathrm{~B}$ managers have not made any changes to their menu. Furthermore, F\&B managers lessen the number of menu items to handle the food cost better and to reduce food waste. In terms of operational hours, 10 out of $15 \mathrm{~F} \& \mathrm{~B}$ managers agreed that they had not changed their operating hours, whereas MGR1, MGR2, MGR3, MGR4, and MGR7 have opened just for dinner. In terms of customer satisfaction, the most of the $F \& B$ managers indicated that customer satisfaction and service quality levels have not affected. However, MGR2, MGR12, MGR13, and MGR8 showed that customer satisfaction levels are noticeably decreased. Surprisingly, MGR1, MGR9, and MGR10 showed an increase in guest satisfaction in their hotels because they have an action plan to handle customer complaints during crises (see Table 4 in the next page). 
Table 4: Effects of Crises in Hotel Restaurants

\begin{tabular}{|l|c|c|c|}
\hline \multicolumn{1}{|c|}{ Attributes } & Increased & Declined & Stable \\
\hline Average annual occupancy of restaurants & 0 & 14 & 1 \\
\hline Average number of guests & 0 & 15 & 0 \\
\hline Number of reservations cancelled & 15 & 0 & 0 \\
\hline The profitability of hotel restaurants & 0 & 15 & 0 \\
\hline Cost reduction of hotel restaurants & 15 & 0 & 0 \\
\hline Menu prices of restaurants & 0 & 2 & 13 \\
\hline Operational hours in restaurants & 0 & 5 & 10 \\
\hline Guest seat turnover & 0 & 15 & 0 \\
\hline Guest satisfaction & 3 & 4 & 8 \\
\hline Number of staff & 1 & 11 & 3 \\
\hline Staff performance & 2 & 12 & 0 \\
\hline Staff satisfaction & 2 & 12 & 0 \\
\hline Service quality & 3 & 0 & 12 \\
\hline Restaurant offers & 15 & 0 & 0 \\
\hline Menu variety & 1 & 12 & 2 \\
\hline
\end{tabular}

\section{Operational Procedures of Hotel Restaurants during Crisis Periods}

This question aims to identify F\&B managers' operational processes before and during crises. Before crises, all $\mathrm{F} \& \mathrm{~B}$ managers confirmed that most action plans used before these periods have focused on marketing packages. Some F\&B managers (e.g., MGR5; MGR9 and MGR14) revealed that they do not have a crisis management plan to reduce the harmful effects of crisis when it happens. During crises, committee members typically hold a meeting to discuss different action plans. This committee consists of the Executive Chef, F\&B Manager, Human Resources Manager, Sales, and Marketing Manager. MGR2 indicated that the F\&B manager has worked with restaurant managers to put 'staff zero base system". A staff zero base system indicates the number of employees that they can run the operation during crises, which require rearrange the organization chart based on a situation. Moreover, MGR2 has created a new method called 'creative team,' which contains members from all restaurants with different positions to develop new ideas, such as: saving cost, promotion, marketing plan, and new menu items. MGR10 indicated that we had conducted $\mathrm{F} \& \mathrm{~B}$ promotions in order to increase sales during crises as follows: buy two set menus and get one free; buy one dessert and get the second free; eat at the buffet restaurant and get drinks free.

\section{Evaluation of Action Plans During Crises}

Five out of fifteen F\&B managers, i.e., MGR4, MGR3, MGR12, MGR13, and MGR8, agreed that the cost-saving plan was very active and worked well during crises. These $F \& B$ managers used maintenance and cost reduction plans by limiting opening restaurant days and hours, reducing the lighting after midnight in restaurants, cutting costs by using less expensive substitutes to prepare food items in the kitchen. On the other hand, MGR2 argued that saving electricity bills were the most issue of cost-saving plans because it didn't work well with restaurants. Besides, reducing menu prices and the number of menu items has not satisfied regular customers since menus prices are unnecessary. 


\section{Results of the Quantitative Study}

\section{Respondent's Profile}

The findings indicated that $68.1 \%$ of the hotel employees were males, compared to only $31.9 \%$ of females. (see Table 8). Around $65 \%$ of the respondents' age ranged from 20 to 40 years. The results also showed that $47.5 \%$ of respondents were unmarried, compared to $17.5 \%$ were married couples with children.

Table 5: Respondent's Profile

\begin{tabular}{|l|l|c|c|}
\hline \multicolumn{2}{|c|}{} & Frequency & Percent \\
\hline \multirow{3}{*}{ Gender } & Male & 218 & 68.1 \\
\cline { 2 - 4 } & Female & 102 & 31.9 \\
\hline \multirow{4}{*}{ Age } & Less than 20 years & 44 & 13.8 \\
\cline { 2 - 4 } & From 20 to 30 years & 100 & 31.3 \\
\cline { 2 - 4 } & From 31 to 40 years & 108 & 33.8 \\
\cline { 2 - 4 } & More than 40 years & 68 & 21.3 \\
\hline \multirow{3}{*}{$\begin{array}{l}\text { Marital } \\
\text { status }\end{array}$} & Single & 152 & 47.5 \\
\cline { 2 - 4 } & Married without children & 56 & 17.5 \\
\cline { 2 - 4 } & Married with children & 112 & 35.0 \\
\hline
\end{tabular}

\section{Customers' Frequency}

This question aimed to identify how many times each customer visits the hotel restaurants during the crisis period. As noticed in Table 6, most customers have visited a hotel restaurant once a month, while around $5 \%$ of customers have visited more than three times

Table 6: Number of Customers' Visits to Hotel Restaurants during Crises a Month

\begin{tabular}{|c|c|c|c|}
\hline & Frequency & Percentage & Ranking \\
\hline Once in a month & 136 & 42.5 & 3 \\
\hline $\begin{array}{c}\text { Twice in a } \\
\text { month }\end{array}$ & 58 & 18.1 & 4 \\
\hline Third in a month & 38 & 11.9 & 2 \\
\hline $\begin{array}{c}\text { More than three } \\
\text { times in a month }\end{array}$ & 70 & 21.9 & 5 \\
\hline Others & 18 & 5.6 & - \\
\hline Total & 320 & 100.0 & \\
\hline
\end{tabular}

\section{Quality and Variety of Food Offered in Hotel Restaurants}

The results showed that $26.3 \%$ of respondents evaluated the quality of food provided as fair compared to $25 \%$ excellent. The results showed that $23.8 \%$ of customers assessed the quantity of food in the restaurant as good, $18.8 \%$ compared to $5.6 \%$ as very poor. The findings indicated that $31.3 \%$ of customers evaluated a variety of food offered as good, while $8.1 \%$ of customers rated the variety of food as poor. Some customers commented that restaurant hotels did not have children and vegetarian items during crisis periods.

\section{Customer Perceptions of Hotel Restaurant Procedures during the Crises Period}

This question aims to know to what extent the operational methods applied in restaurants to keep the quality of the service consistent during the crisis (see Table 7 in the next page). The findings indicated that $73.1 \%$ of respondents strongly agreed on reducing menu pricing; $68.8 \%$ of respondents feel strongly agree also about adding a special set menu. On 
the other hand, $78 \%$ of customers disagreed about decreasing menu items, and $70 \%$ of customers even strongly disagreed about lowering the quality of menu items.

Table 7: Customer Perceptions of Hotel Restaurant Procedures during the Crises Period

\begin{tabular}{|c|c|c|c|c|c|c|c|c|c|c|c|}
\hline \multirow{2}{*}{ Items } & \multicolumn{2}{|c|}{$\begin{array}{c}\text { Strongly } \\
\text { agree }\end{array}$} & \multicolumn{2}{|c|}{ Agree } & \multicolumn{2}{|c|}{ Neutral } & \multicolumn{2}{|c|}{ Disagree } & \multicolumn{2}{|c|}{$\begin{array}{l}\text { Strongly } \\
\text { disagree }\end{array}$} & \multirow{2}{*}{ Std } \\
\hline & Freq & $\%$ & Freq & $\%$ & Freq & $\%$ & Freq & $\%$ & Freq & $\%$ & \\
\hline Reduce menu prices & 234 & 73.1 & 34 & 10.6 & 38 & 11.9 & 8 & 2.5 & 6 & 1.9 & 0.93 \\
\hline $\begin{array}{l}\text { Price drops on special } \\
\text { offers }\end{array}$ & 186 & 58.1 & 90 & 28.1 & 34 & 10.6 & 4 & 1.3 & 6 & 1.9 & 0.868 \\
\hline $\begin{array}{l}\text { Add a new menu or } \\
\text { changing the currant } \\
\text { menu offering }\end{array}$ & 180 & 56.3 & 80 & 25 & 40 & 12.5 & 16 & 5 & 4 & 1.3 & 0.96 \\
\hline $\begin{array}{l}\text { Extend hours or days of } \\
\text { menu }\end{array}$ & 200 & 62.5 & 70 & 21.9 & 42 & 13.1 & 4 & 1.3 & 4 & 1.3 & 0.86 \\
\hline $\begin{array}{l}\text { Add special set menu } \\
\text { with special price or } \\
\text { groups }\end{array}$ & 220 & 68.8 & 62 & 19.4 & 30 & 9.4 & 4 & 1.3 & 4 & 1.3 & 0.8 \\
\hline $\begin{array}{l}\text { Menu price was included } \\
\text { in the package }\end{array}$ & 180 & 56.3 & 72 & 22.5 & 44 & 13.8 & 12 & 3.8 & 12 & 3.8 & 1.1 \\
\hline Decrease the menu items & 38 & 11.9 & 20 & 6.3 & 24 & 7.5 & 78 & 24.4 & 160 & 50 & 1.4 \\
\hline $\begin{array}{l}\text { Decrease the quality of } \\
\text { menu items }\end{array}$ & 30 & 9.4 & 0 & 0 & 8 & 2.5 & 58 & 18.1 & 224 & 70 & 1.2 \\
\hline
\end{tabular}

\section{Hotel Restaurants' Promotions during Crises}

The findings indicated $72.5 \%$ of respondents strongly agreed to offer all-inclusive services during crises (see Table 8 in the next page). The results also showed that $63.1 \%$ of respondents strongly agreed about reducing the service minimum charge in à la carte hotel restaurants and adding different kinds of promotions in buffet restaurants.

Table 8: Hotel Restaurants' Promotions during Crises

\begin{tabular}{|c|c|c|c|c|c|c|c|c|c|c|c|}
\hline \multirow{2}{*}{ Items } & \multicolumn{2}{|c|}{$\begin{array}{l}\text { Strongly } \\
\text { agree }\end{array}$} & \multicolumn{2}{|c|}{ Agree } & \multicolumn{2}{|c|}{ Neutral } & \multicolumn{2}{|c|}{ Disagree } & \multicolumn{2}{|c|}{$\begin{array}{l}\text { Strongly } \\
\text { disagree }\end{array}$} & \multirow{2}{*}{ Std } \\
\hline & Freq & $\%$ & Freq & $\%$ & Freq & $\%$ & Freq & $\%$ & Freq & $\%$ & \\
\hline $\begin{array}{l}\text { Add kids' corner in } \\
\text { restaurants }\end{array}$ & 174 & 54.4 & 40 & 12.5 & 40 & 12.5 & 24 & 7.5 & 42 & 13.1 & 1.5 \\
\hline $\begin{array}{l}\text { Joint offers restaurants } \\
\text { with rooms }\end{array}$ & 156 & 48.8 & 72 & 22.5 & 44 & 13.8 & 22 & 6.9 & 26 & 8.1 & 1.3 \\
\hline $\begin{array}{l}\text { Promote new services such } \\
\text { as catering, events, etc. }\end{array}$ & 188 & 58.8 & 60 & 18.8 & 58 & 18.1 & 4 & 1.3 & 10 & 3.1 & 1.01 \\
\hline $\begin{array}{l}\text { Add different kinds of } \\
\text { promotions in buffet } \\
\text { restaurants }\end{array}$ & 196 & 61.2 & 56 & 17.5 & 45 & 16.9 & 8 & 2.5 & 15 & 4.6 & 0.96 \\
\hline $\begin{array}{l}\text { Reliance joint marketing } \\
\text { campaigns with other } \\
\text { merchants such as Visa or } \\
\text { Master card }\end{array}$ & 192 & 60 & 58 & 18.1 & 46 & 14.4 & 12 & 3.8 & 12 & 3.8 & 1.07 \\
\hline $\begin{array}{l}\text { Extend the marketing to } \\
\text { new segments }\end{array}$ & 156 & 48.8 & 46 & 14.4 & 70 & 21.9 & 26 & 8.1 & 22 & 6.9 & 1.03 \\
\hline $\begin{array}{l}\text { Sufficient advertising in } \\
\text { media }\end{array}$ & 140 & 43.8 & 72 & 22.5 & 80 & 25 & 12 & 3.8 & 16 & 5 & 1.13 \\
\hline Reduce minimum charge & 202 & 63.1 & 62 & 19.4 & 44 & 13.8 & 6 & 1.9 & 6 & 1.9 & 0.92 \\
\hline $\begin{array}{l}\text { Creation of all-inclusive } \\
\text { services }\end{array}$ & 232 & 72.5 & 30 & 9.4 & 38 & 11.9 & 8 & 2.5 & 12 & 3.8 & 1.04 \\
\hline
\end{tabular}




\section{Discussion}

This study investigated the operational procedures adopted by hotel restaurants during crises. The current study examined the role of F\&B managers during crises. This study also probed the relationship customer perceptions about the quality of food and operational procedures of hotel restaurants during crises. The findings revealed a dramatic decrease in the number of tourists and the cancellation of restaurant reservations. Some of the hotel restaurants are even closed after the Egyptian revolution of 2011. Page and Connell (2009) explained that political unrest in tourist destinations leads to a decrease in the number of international tourist arrivals, shortening of the duration of stay and tourist nights, reduction in hotel room occupancy rates, declining tourism revenues, and increasing the percentage of unemployment. The annual occupancy rate in 2011 sharply decreased by $38.2 \%$ compared to occupancy rates of 2008 , which represents a considerable decline in hotel occupancy rates in Cairo in Egypt (Egyptian Ministry of Tourism, 2011).

In addition, the findings of this study noted that hotels close to Tahrir Square changed their operational plan in their restaurants because guests are more worried about their safety and security. This finding goes in line with Ritchie (2009) that political instability can severely impact tourism in any destination because eventually, tourists may become victims of these events. Political incidents have a more prolonged and more severe effect on destinations than natural disasters (Beirman, 2002). For example, politically unstable countries suffer a range of negative consequences, including reduced cash flow, loss of foreign investment, perceptions of hostility by potential visitors, unstable demand, negative image and reputation, low quality of infrastructure and safety and security concerns (Issa and Altinay, 2006).

In the context of employees' satisfaction, the findings indicated that employees' turnover increased dramatically because most qualified employees have traveled abroad to find a better place to work. Only $30 \%$ of workers on restaurants remained on duty; however, 50\% were given unpaid vacations. The reason was most of the hotel restaurants were shut down entirely during the Egyptian revelation of 2011. The findings indicated that some hotels had built a staff zero base system, revealing the number of employees the operation during crises. Many hotels have had to eliminate or simply not replace certain key positions so that the remaining employees have taken on additional responsibilities, multitasking becoming the norm.

Meanwhile, staff performance and satisfaction were significantly dropped because of cutting off their benefits, such as service charges and tipping. Greenberg (2012) reported that of more than 400 hotel restaurants, only 80 were operating. As a result of this enormous discharge of hotel employees, the percentage of unemployment in Egypt increased, resulting in more labor strikes and exacerbated the unstable atmosphere still further. In terms of customer satisfaction, the majority of F\&B managers indicated that customer satisfaction and service quality levels have not affected. However, MGR2, MGR12, MGR13, and MGR8 showed that customer satisfaction levels are noticeably decreased. The questionnaire analysis of this study showed that most customers had visited a hotel restaurant once a month, while around 5\% of customers have visited more than three times a month. Surprisingly, MGR1, MGR9, and MGR10 showed an increase in guest satisfaction in their hotels because they have an action plan to handle customer complaints during crises.

Moreover, this study examined F\&B managers' operational plans before and during crises. F\&B managers revealed that most action plans have focused on marketing packages before crises happen. Some F\&B managers (e.g., MGR5; MGR9 and MGR14) indicated 
that they do not have a crisis management plan to reduce the harmful effects of crisis when it happens. This result is compatible with what has been reported by Nassar (1995) when he described crisis management as the organized and systematic effort of an operation to prevent, react to, and learn from crises and development of crisis management plan, which is one mark of proactive rather than reactive management.

The findings of this study also indicated that committee members typically hold a meeting to discuss different action plans during crises. This committee consists of the Executive Chef, F\&B Manager, Human Resources Manager, Sales, and Marketing Manager. Hotels should have a plan for operational restaurants to face crisis because the crisis leader can't work alone (Boin, 2000). The crisis plan should designate a crisis team relay the leader's directives to the other employees. This team can also participate in the decision-making process and inform the leader of issues that need to be resolved.

Furthermore, this study showed that customers were satisfied with the quality, quantity, and variety of food offered in the sampled hotel restaurants during crises. Even though customers were highly agreed on reducing menu prices and extending hours or days of hotel restaurant operations during crises, customers strongly disagreed about reducing the number and quality of menu items, such as children and vegetarian items. The results also indicated that most customers highly agreed on lowering the minimum charge and creating all-inclusive offers during crises. However, many of the hotels have drastically reduced prices during crises will be faced with difficulties when they try to bring prices to a profitable level.

\section{Conclusion}

A crisis is a significant occurrence with a potentially harmful outcome affecting an organization. Crisis management has become one of the most important managerial skills that every manager should have. Successful businesses during crises continuously seek ways of improving their profitability. In circumstances where gross profit margins can be improved, the overall net profit of the company can be uplifted.

The findings of this study suggest meaningful theoretical implications for researchers. First, this study identified how customers perceived the quality of food and the operational procedure of hotel restaurants during crises. Thus, this research will provide a backbone for future academics who wish to expand knowledge of hotel operational procedures during crises. This study also provides some meaningful managerial implications. The findings showed that hotel managers should focus on offering a variety of menus to suit different guest segments. They also have to focus on making offers and promotions to attract more customers during crises. For instance, combining restaurants specials with room rent reliance on joint marketing campaigns with other merchants, such as Visa or Master card; and reducing minimum charge in hotel restaurants. Hotel restaurant managers should maintain consistency by applying strict principles of portion control. Crisis management has become one of the most important managerial skills that every manager should have. It is also a critical source of satisfying customers and improving the quality of service in restaurants during crises.

Furthermore, F\&B managers must have a plan to operate their restaurants during the crisis period. This plan should designate a crisis team that will relay the leader's directives to the other employees. This team should include an F\&B manager, restaurant manager, and marketing manager. A possible means of cutting costs is to reduce factor input costs, which could be done through negotiation with food suppliers to lower the cost 
of food products, with staff for a pay cut or no pay leave, and with the government to reduce the water and electricity costs.

\section{Limitations and Future Research}

Despite the contributions made by this study to the crisis management literature, it has limitations that need to be addressed and suggest potential avenues for future research. First, the generalization of the results might be limited because the sample comprised employees of five-star hotels in Egypt. Therefore, a cross-cultural study in different cultural groups will help validate the results of the study. Second, this research conducted semi-structured interviews with F\&B managers. Future research, for example, can conduct interviews with the policymakers to gain a more comprehensive understanding of crisis management in the Egyptian hospitality industry. Finally, this study examined the perceptions of customers and employees in five-star hotels regarding operational procedures of hotel restaurants during crises. It would help address this issue in different hospitality industry sectors, such as floating hotels or fast-food restaurants.

\section{References}

Abou-El-Fadl, R. (2012). Beyond Conventional Transitional Justice: Egypt's 2011 Revolution and the Absence of Political Will. International Journal of Transitional Justice, 6(2), 318-330.

Abu al-Khair, W. (2011), "Egyptian tourism industry hopes for quick recovery", available online: https://www.theguardian.com/travel/2016/oct/21/egypt-tourism-industryplagued-by-lack-of-visitors (Accessed 10-4-2014).

Aziz, H. (1995). Understanding terrorist attacks on tourists in Egypt. Tourism Management, 16, 91-95.

Barrows, W., \& Powers, T. (2009). Introduction to management in the hospitality industry. (Ninth Edition). John Wiley \& Sons, Inc, USA.

Barton, L. (1993). Crisis in Organizations: Managing and Communicating in the Heat of Chaos. South-Western Publishing Co., Australia.

Barton, L. (2008). Crisis leadership now: a real-world guide to preparing for threats, disaster, sabotage, and scandal. McGraw-Hill, New York.

Beirman, D. (2002). Marketing of tourism destinations during a prolonged crisis: Israel and the Middle East. Journal of Vacation Marketing, 8,167-187.

Beirman, D. (2003). Restoring Tourism Destinations in Crisis. CABI Publishing, London.

Boin, A., \& Lagadec, P. (2000). Preparing for the future: Critical challenges in crisis management. Journal of Contingencies and Crisis Management, 8, 185-191.

Brewton, C. (1987). Managing a Crisis: A Model for the Lodging Industry. Cornell Hotel and Restaurant Administration Quarterly, 10-13.

Egerton, C. (2006). How to Open and Run a Successful Restaurant. (Third Edition). John Wiley and Sons, Inc., New Jersey.

Egyptian Ministry of Tourism (2010). Egyptian Hotel Guide. Egyptian Hotel Association. Cairo, Egypt.

Glaesser, D. (2003). Crisis management in the Tourism Industry. Butterworth-Heinemann, Oxford.

Greenberg, P. (2012). The travel detective: Is Egypt safe? Available online: https://www.huffpost.com/entry/the-travel-detective-on-t_b_1205841 (Accessed 08-08-2020) 
Iordache, C. (2013). Management strategies of the financial -Economic crisis in the hotel's domain. Theoretical and applied economics, 9 (586), 115-126.

Issa, I., \& Altinay, L. (2006) Impact of political instability on tourism planning and development: the case of Lebanon. Tourism Economics, 12, 361-381.

Jeffrey, D., \& Barden R. (2000). An analysis of daily occupancy performance: a basis for effective hotel marketing. International Journal of Contemporary Hospitality Management, 12, 179-189.

Johnston, R., and Clark, G. (2001). Service Operation Management. Prentice-Hall, London.

Leslie, D. (1996). Northern Ireland, tourism and peace. Tourism Management, 17 (1), 5155.

Mahfouz, H. (1998), Overcoming Crises in Hotel Industry. Unpublished Master Thesis, Faculty of Tourism and Hotel Management, Helwan University.

Malhotra, R., \& Venkatesh, U. (2009). Pre-crisis period planning: lessons for hospitality and tourism. Worldwide Hospitality and Tourism Themes. 1 (1), 66-74.

Nassar, N. (1995). Tourism Crises and How to Handle them. Unpublished Master Thesis, Faculty of Tourism and Hotel Management, Helwan University.

Page, S., \& Connell, J. (2009). Tourism: a modern synthesis. Cengage Learning EMEA, UK.

Phelps, J. (1991). Preventing Chaos in Crisis. McGraw-Hill Book Co., New York.

Powers, T., \& Barrows, C. (2003). Introduction to Hospitality Industry. Seventh Edition. John Wiley and Sons, Inc., New Jersey.

Ribaric, R. (2010). Implementation of new risk management opportunities in crisis management. Tourism and Hospitality Management, Conference proceedings, 570577.

Ritchie, B. (2009). Crisis and disaster management for tourism. UK, Channel View Publications.

Robbins, S., \& Coulter, M. (2003). Management. Prentice-Hall, New Jersey.

Saunders, M., Lewis, P. \& Thornhill, A. (2012). Research Methods for Business Students. Sixth Edition. England, Person Education Limited.

Stafford, G., Yu, L., \& Kobina, A. (2002). Crisis Management and Recovery: How Washington, DC, Hotels Responded to Terrorism. Cornell Hotel and Restaurant Administration, 43 (5), 28-30.

Ulmer, R., \& Sellnow, T. (2000). Consistent questions of ambiguity in organizations crisis communication: Jack in the Box as a case study. Journal of Business Ethics, 25 (2), 143-155.

World Tourism Organization (2003). Crisis Guidelines for the Tourism Industry. Fourth Meeting of the Tourism Recovery Committee. Berlin, Germany.

Yin, R. (2013). Case Study Research: Design and Methods. Fifth Edition. Thousand Oaks, CA, Sage Publications. 